\title{
DIFFERENTIATIVE CHANGES IN FUCOSYLTRANSFERASE ACTIVITY IN NEWBORN RAT EPIDERMAL CELLS
}

\author{
Jianming Xiang and I. A. Bernstein ${ }^{*}$
}

Departments of Environmental and Industrial Health and of Biological Chemistry, 1528 Public Health, The University of Michigan, Ann Arbor, Michigan 48109-2029

Received October 12, 1992

An enzymatic activity catalyzing the transfer of L-fucose from GDP-L-fucose to a glycoprotein that is associated with the surfaces of the basal cells has been found in the membranous fraction of the cutaneous epidermis from the newborn rat. This fucosyltransferase which is located in the differentiated cells alters the acceptor glycoprotein's lectin-binding specificity from the Isolectin I$\mathrm{B}_{4}$ of Griffonia simplicifolia (GS I-B 4 ) to the Agglutinin I of Ulex europeus (UEA) and could be responsible for the same change in lectin-binding specificity that occurs as the epidermal basal cell differentiates. Another membraneous fucosyltransferase that can use asialofetuin - but not the GS I- ${ }_{4}$ binding glycoprotein - as an acceptor, is also present in the membraneous fraction.

(c) 1992 Academic Press, Inc.

Lectin-binding has demonstrated that alteration in the chemical structure of glycoconjugates found on the cell surface is associated with the progression of morphological change which characterizes differentiation in the mammalian cutaneous epidermis (1-5) as well as other mammalian cells and tissues (cf., 2). One such alteration observed by lectin-binding appears to be closely linked to the movement of epidermal basal cells into the spinous layer. It was shown (1) that the Isolectin $I-B_{4}$ from Griffonia simplicifolia (GS I-B , $_{4}$ with specificity for $\alpha$-D-galactoside binds to basal cells and the cells in the lower layers of the spinous compartment. On the other hand, Agglutinin I of Ulex europeus (UEA) with specificity for $\alpha$-L-fucoside, does not bind to basal cells but does bind to the cells in the spinous and lower granular layers. When epidermal tissue was treated with $\alpha$-L-fucosidase, UEAbinding was eliminated and binding by GS $\mathrm{I}-\mathrm{B}_{4}$ was present throughout the spinous layer (2). After tissue was incubated with $\alpha$-D-galactosidase, GS I-B ${ }_{4}$ did not bind but exposure to this hydrolase did not result in the appearance of additional UEA-binding (3). Glycoprotein which exhibited specificity for GS I-B $\mathrm{B}_{\mathbf{4}}$ was converted to UEA-binding after incubation with an epidermal homogenate while glycoprotein with specificity for UEA, could bind to GS I-B $_{4}$ after treatment with $\alpha$-L-fucosidase. (6).

\footnotetext{
* To whom correspondence should be addressed.
} 
Available evidence supports the view that these proteins which differ in their lectin-binding specificity are similar in other respects (7). These observations suggested that the cutaneous epidermis of the newborn rat possesses the necessary transferase - presumably in the spinous cells - to convert glycoprotein found on the cell surface from hinding-specificity for GS I-B $_{4}$ to specificity for UEA during differentiation by the addition of L-fucose to non-reducing, terminal $\alpha$-D-galactosyl residues on glycoconjugates with specificity for GS I-B . $_{4} \quad$ Data in the present report indicate that in the epidermis of the newborn rat there are at least two fucosyltransferases associated with the cell surface.

One of these enzymes, found primarily in the differentiated population of cells, could be the one that is responsible for the change in lectin-binding specificity on the cell surface that is observed as the basal cell moves into the spinous layer.

\section{MATERIALS AND METHODS}

Materials. GS I-B 4 , UEA, L-fucose, methyl- $\alpha-D$-galactoside, Sepharose 4B, asialofetuin, Triton X100 and NP-40 (Nonidet P-40) were purchased from Sigma (St. Louis, MO). [ $\left.{ }^{3} \mathrm{H}\right] \mathrm{NaB}_{4}$ was obtained from NEN Research Products (Boston, MA) and GDP-L-[U- $\left.{ }^{14} \mathrm{C}\right]$-fucose was purchased from Amersham (Arlington Heights, IL)

Separation of Cells from Newborn Rat Epidermis. Epidermal cells were isolated from newborn rats that were $24-48 \mathrm{hr}$ old and were derived from a randomly inbred colony of the CFN strain maintained in this laboratory for the past 20 years. The isolation technique was as described by Zieske and Bernstein (1) with the following slight modifications: the skin was incubated in $10 \mathrm{ml}$ of $1 \%$ crude trypsin in PBS (phosphate buffered saline) for 30-45 min to separate dermis and epidermis; after separation, the underside of the epidermis was brushed into $8 \mathrm{ml}$ of MEM (Eagle's minimum essential medium) containing $10 \%$ fetal calf serum, and the cells were sedimented by centrifugation at $60 \times g$ for $10 \mathrm{~min}$ at $4^{\circ} \mathrm{C}$.

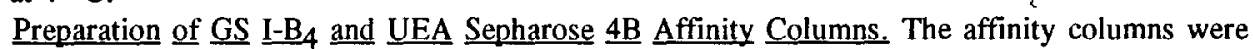

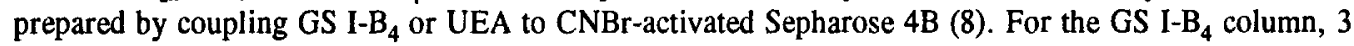
$\mathrm{mg}$ of the lectin were mixed with $0.3 \mathrm{~g}$ of $\mathrm{CNBr}$-activated Sepharose 4B. For the UEA column, $4 \mathrm{mg}$ of UEA were mixed with $0.5 \mathrm{~g}$ of $\mathrm{CNBr}$-activated Sepharose $4 \mathrm{~B}$. The procedure for preparing both columns was the same except that $0.5 \mathrm{mM}$ methyl- $\alpha$-galactoside was present in the reaction mixture

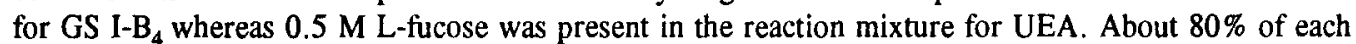
lectin was bound to the $\mathrm{CNBr}$-activated Sepharose $4 \mathrm{~B}$.

Labeling and Isolation of Cell Surface Glycoprotein that has Binding specificity for GS I-B 4 . The labeling method incorporates ${ }^{3} \mathrm{H}$ from $\left[{ }^{3} \mathrm{H}\right] \mathrm{NaBH}_{4}$ at the $\mathrm{C}-6$ position of Gal and GalNAC residues $(9, \mathrm{cf} ., 7)$. Cells from 15 pieces of skin taken from the backs of newborn rats were suspended in $0.9 \mathrm{ml}$ of PBS and $0.1 \mathrm{ml}$ of $10 \mathrm{mM} \mathrm{NaBH}_{4}$ in $10 \mathrm{mM} \mathrm{NaOH}$. The cells were incubated at room temperature for $30 \mathrm{~min}$ and then washed 3 times with PBS. They were resuspended in $1 \mathrm{ml}$ of PBS containing 20 units of galactose oxidase and incubated at $37^{\circ} \mathrm{C}$ for $30 \mathrm{~min}$ with shaking. The cells were again washed 3 times with PBS, resuspended in $0.9 \mathrm{ml}$ of $\mathrm{PBS}$ and $0.1 \mathrm{ml}$ of $\left[{ }^{3} \mathrm{H}\right] \mathrm{NaBH}_{4}(1 \mathrm{mCi})$ in $10 \mathrm{mM} \mathrm{NaOH}$ and were incubated at room temperature for $30 \mathrm{~min}$. Unreacted [ $\left.{ }^{3} \mathrm{H}\right] \mathrm{NaBH}_{4}$ was removed by washing the cells 3 times with PBS. Next, the cells were resuspended in $1 \mathrm{ml}$ of PBS containing $0.5 \% \mathrm{NP}-40$ and then incubated at $4^{\circ} \mathrm{C}$ for 1 hour. The mixture was finally centrifuged at $12,800 \mathrm{xg}$ for $10 \mathrm{~min}$ and the resulting pellet was discarded. The supernatant solution was applied to

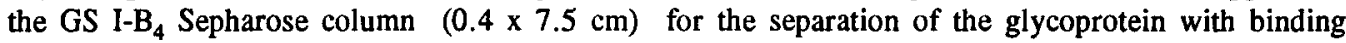

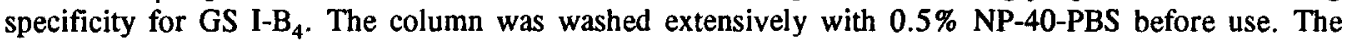
supernatant solution from the step above was applied to the column at a flow rate of $2-4 \mathrm{ml} / \mathrm{h}$. The column was rinsed with at least 5 bed volumes of $0.5 \%$ NP-40-PBS to remove nonspecific-binding material. This material appeared as a single band between 2.7 and $6.3 \mathrm{ml}$ in the elution profile shown 
in Figure 1. Glycoprotein with binding-specificity for GS I-B B $_{4}$ was eluted with methyl- $\alpha$-D-galactoside $(20 \mathrm{mg} / \mathrm{ml}$ in $0.5 \% \mathrm{NP}-40-\mathrm{PBS})$ between 19.8 and $21.6 \mathrm{ml}$. The peak fractions of the eluate were dialyzed against $0.5 \%$ NP-40-PBS to remove the methyl- $\alpha$-D-galactoside and stored at $4^{\circ} \mathrm{C}$.

Cell Fractionation. Differential centrifugation was used to fractionate the cells (cf., 10). All procedures were performed at $4^{\circ} \mathrm{C}$. Cells from 24 pieces of newborn rat epidermis were suspended in $10 \mathrm{mM}$ Tris buffer, $\mathrm{pH} 7.0$, containing $10 \mathrm{mM} \mathrm{MgCl}_{2}, 10 \mathrm{mM} \mathrm{KCl}$, and $0.25 \%$ sucrose and sonicated four times for 15 seconds each time. The cell homogenate was centrifuged at $600 \mathrm{xg}$ for $10 \mathrm{~min}$. The pellet which contained large fragments of plasma membrane (cf., 10) was resuspended in the same buffer (Fraction 1) while the supernatant solution was centrifuged again at 100,000 xg for $1 \mathrm{hr}$. The pellet from the second centrifugation which included mitochondria, endoplasmic reticulum and small fragments of the plasma membrane, was resuspended in the same buffer and again sonicated four times for 15 seconds each (Fraction 2) to suspend the solid material. The final supernatant solution represented the soluble fraction of the cell (Fraction 3).

Assay of Fucosyltransferase Activity. The fucosyltransferase activity assay measured the amount of $\left[{ }^{14} \mathrm{C}\right]$ fucose associated with either asialofetuin $(14,17)$ or the ${ }^{3} \mathrm{H}$-labeled GS I-B4-binding glycoprotein obtained from a GS I-B4 sepharose 4B column, depending on which acceptor was used. GDP- $\left[{ }^{14} \mathrm{C}\right]$ fucose was the fucosyl donor. The reaction mixture consisted of $0.5 \mathrm{ml}$ of enzyme extract or suspension, $0.1 \mathrm{ml}$ of $\left[{ }^{3} \mathrm{H}\right]$ glycoprotein or asialofetuin and $0.05 \mathrm{uCi}$ of $\mathrm{GDP}-\left[{ }^{14} \mathrm{C}\right]$ fucose. The reaction mixture was incubated at $37^{\circ} \mathrm{C}$ for $3 \mathrm{hr}$ and then dialyzed three times against a liter of $0.5 \%$ NP-40-PBS to remove the unreacted $\left[{ }^{14} \mathrm{C}\right]$ fucose. In the case of asialofetuin as the acceptor, the dialyzed solution was counted for radioactivity in a Packard Tri-Carb liquid scintillation spectrometer. When the ${ }^{3} \mathrm{H}$-labeled glycoprotein was used as acceptor, the reaction mixture was centrifuged and the supernatant solution was applied to the UEA sepharose $4 \mathrm{~B}$ column at a flow rate of $2-4 \mathrm{ml} / \mathrm{h}$. The column was rinsed with at least 5 bed volumes of $0.5 \%$ NP-40-PBS and then eluted with L-fucose (40 $\mathrm{mg} / \mathrm{ml}$ ) in $0.5 \% \mathrm{NP}-40-\mathrm{PBS}$ as shown in Figure 2. Fractions from the column were put into plastic vials with $5 \mathrm{ml}$ of ScintiVers BD and counted in a Packard liquid scintillation spectrometer.

Separation of Basal Cells and Differentiated Cells. The separation of basal cells and differentiated cells was done by sedimentation in a density gradient of Percoll (11). Cells from newborn rat epidermis were resuspended in 38\% isotonic Percoll in EBSS. The suspension was centrifuged at 30,000 xg for $20 \mathrm{~min}$. Two major bands of cells were obtained. Basal cells were in the lower band while differentiated cells stayed in the upper band. Each band of cells was taken from the centrifuge tube, washed with MEM and then used for assay of fucosyltransferase activity assay.

\section{RESULTS AND DISCUSSION}

Cellular distribution of fucosyltransferase activity was investigated by cell fractionation. The acceptor for the enzyme assay in this study was the GS I-B4-binding glycoprotein eluted from the affinity column (cf., Fig. 1). Data in Table 1 demonstrate that nearly $95 \%$ of the fucosyltransferase activity using this acceptor was found in Fraction 1 which contained the large fragments of plasama membrane. The remaining activity was in Fraction 2 which would be expected to have any small fragments of the cell's outer membrane.

Initially in the present study, Triton X-100 was used to extract the fucosyltransferase from the cell membrane fraction since previous studies (12-16) had indicated that the enzyme activity was soluble in detergent. However, when the glycoprotein eluted from the GS I-B 4 column was used as the acceptor in the enzyme assay, no transferase activity was found in the extract. Fucosyltransferase activity could be demonstrated in the extract if asialofetuin were used as the acceptor. When the residue remaining after the extraction with Triton X-100 was resuspended in buffer and used as the 


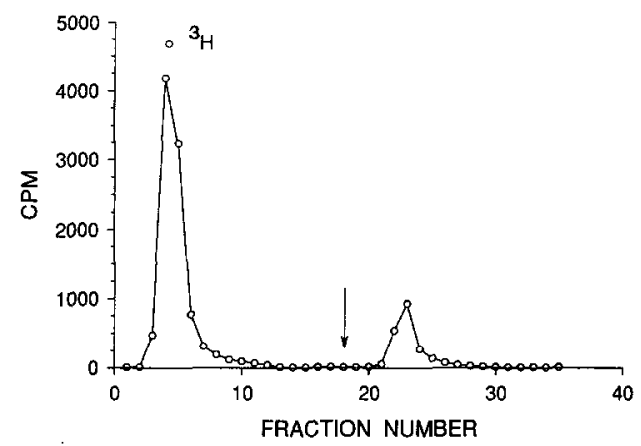

Figure 1. Elution profile of ${ }^{3} \mathrm{H}$-labeled glycoprotein from a column of GS I-B 4 -Sepharose 4B. Volume of each fraction was $0.9 \mathrm{ml}$. Arrow indicates the point at which methyl galactoside was added. For details of procedure, see the text. Dimensions of the column were $\mathbf{0 . 4}$ $\times 7.5 \mathrm{~cm}$.

source of fucosyltransferase, $\left[{ }^{14} \mathrm{C}\right]$ fucose was transferred to the GS I-B 4 -binding glycoprotein as shown in Table 2. The data in this table indicate that, although both enzymatic activities are associated with the membrane, the activity that transfers fucose to the GS I-B 4 -binding glycoprotein but not to asialofetuin is different from the activity that is solubilized by detergent and utilizes asialofetuin but not the GS I-B 4 -binding glycoprotein.

As shown in Figure 2, some ${ }^{14} \mathrm{C}$ appeared in the wash. This was not a result of overloading the column since passing the wash through a regenerated column did not result in additional binding. It is probable that the ${ }^{14} \mathrm{C}$ in the wash represented fucosylation of the acceptor protein at sites other than those leading to UEA-binding.

Table 3 shows that fucosyltransferase activity per unit of DNA using the GS I-B4-binding glycoprotein as acceptor was more than six times greater in differentiated cells as compared with

Table 1. Fractionation of fucosyltransferase activity derived from cells of the cutaneous epidermis of the newborn rat

\begin{tabular}{cccccc} 
Fraction & $\begin{array}{c}\text { Total volume } \\
\text { of fraction (ml) }\end{array}$ & $\begin{array}{c}\text { Aliquot used } \\
\text { for reaction (ml) }\end{array}$ & $\begin{array}{c}\text { Enzyme activity } \\
(\mathrm{cpm})\end{array}$ & $\begin{array}{c}\text { Total } \\
\text { enzyme activity } \\
\text { in fraction (cpm) }\end{array}$ & $\begin{array}{c}\% \\
\text { of total } \\
\text { activity in fraction }\end{array}$ \\
\hline 1 & 1.5 & 0.5 & 281 & 844 & 94 \\
2 & 1.0 & 0.5 & 25 & 50 & 6 \\
3 & 2.0 & 0.5 & 0 & 0 & 0 \\
\hline
\end{tabular}

${ }^{3} \mathrm{H}$-labeled glycoprotein from the cell surface was used as the acceptor. GDP-[ $\left.{ }^{14} \mathrm{C}\right]$ fucose was the donor. Enzymatic activity was measured by the transfer of ${ }^{14} \mathrm{C}$ from GDP-[ $\left.{ }^{14} \mathrm{C}\right]$ fucose to acceptor. For other details of procedure see the text. 
Table 2. Acceptors for epidermal membranous fucosyltransferases. Enzymatic activity measured by the transfer of $\left[{ }^{14} \mathrm{C}\right]$ fucose from GDP- $\left[{ }^{14} \mathrm{C}\right]$ fucose to the acceptor

\begin{tabular}{|c|c|c|c|}
\hline \multicolumn{2}{|c|}{ Membraneous fraction } & Acceptor & Enzymatic activity \\
\hline \multicolumn{2}{|c|}{ Triton X-100 extract } & Asialofetuin & 310 \\
\hline$"$ & $"$ & {$\left[{ }^{3} \mathrm{H}\right]$ glycoprotein } & 0 \\
\hline$"$ & $"$ residue & Asialofetuin & 124 \\
\hline$"$ & $"$ & {$\left[{ }^{3} \mathrm{H}\right]$ glycoprotein } & 76 \\
\hline
\end{tabular}

$5,000 \mathrm{cpm}$ of GDP- $\left[{ }^{14} \mathrm{C}\right]$ fucose were added to the reaction mixture. For other details of procedure, see the text.

basal cells. This finding is not surprising given the pattern of UEA-binding in the cutaneous epidermis of the newborn rat (1). The value for the differentiated cells may be even greater than the value observed since a population of differentiated cells prepared by the procedure utilized in the present study is usually contaminated to about $10 \%$ with basal cells (18), The value determined for fucosyltransferase activity in the basal cells may represent a low level of activity in all the basal cells, high activity in the small number of cells which, though differentiated, have not yet moved into the lower spinous layer, or contamination with differentiated cells. The last alternative seems unlikely since the population of basal cells prepared in this manner usually consists of at least $95 \%$ viable germinative cells with little obvious contamination from differentiated cells as observed microscopically. Photomicrographs showing the pattern of UEA-binding in the rodent epidermis (1) argue for the first alternative since they show a relatively low level of fluorescence on the surfaces of

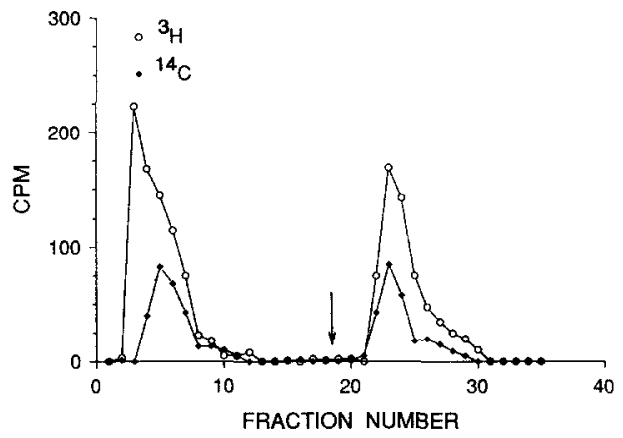

Figure 2. Elution profile of ${ }^{14} \mathrm{C}$-labeled protein in the fucosyltransferase reaction mixture after chromatography on a column of UEA-Sepharose 4B. Volume of each fraction was 0.9 $\mathrm{ml}$. Arrow indicates the point at which fucose was added. Dimensions of the column were $0.4 \times 7.5 \mathrm{~cm}$. For details of procedure, see the text. 
Table 3. Relative levels of fucosyltransferase, which takes ${ }^{3} \mathrm{H}$-glycoprotein as acceptor, in epidermal basal and differentiated cells

\begin{tabular}{|c|c|c|c|}
\hline Cell type & $\begin{array}{c}\mu \mathrm{g} \mathrm{DNA} / 0.5 \mathrm{ml} \text { enzyme } \\
\text { suspension }\end{array}$ & $\begin{array}{c}\text { Total cpm/reaction } \\
\text { mixture }\end{array}$ & $\mathrm{cpm} / 100_{\mu \mathrm{g}}$ DNA \\
\hline Basal & 727 & 84 & 12 \\
\hline Differentiated & 800 & 599 & 75 \\
\hline
\end{tabular}

The Triton X-100 residue was resuspended in buffer and used as the source of enzyme zafter dialysis. Volume of the dialysates were $0.61 \mathrm{ml}$ for the sample from the basal cells and $0.59 \mathrm{ml}$ for the sample from the differentiated cells. $5,000 \mathrm{cpm}$ of GDP-[ ${ }^{14} \mathrm{Cl}$ fucose were used as the donor. $0.5 \mathrm{ml}$ of the Triton X-100 residue resuspended in buffer was used as the enzyme suspension. Final volume of the reaction mixture was $0.62 \mathrm{ml}$. For other details of procedure, see the text.

most basal cells. In any case, the fucosyltransferase that catalyzes the fucosylation of the GS I-B $4^{-}$ binding glycoprotein appears to be associated with an early step in epidermal differentiation. Whether the increase in this enzymatic activity is a cause or a result - or a coincidence - of the cell's initiating the differentiative process is yet to be determined. It is also uncertain whether the increase in active enzyme is a result of synthesis of catalytic molecules or activation of pre-existing molecules. Resolution of these uncertainties should assist in understanding regulatory mechanisms in cellular differentiation.

\section{REFERENCES}

1. Brabec, R.K., Peters, B.P., Bernstein, I.A., Gray, R.H., and Goldstein, I.J. (1980) Proc. Natl. Acad. Sci. (USA), 77, 477-479.

2. Zieske, J.D. and Bernstein, I.A. (1982) J. Cell Biol., 95, 626-631.

3. Nemanic, M.K.,Whitehead, J.S., and Elias, P.M. (1983) J. Histochem. Cytochem., 31, 887-897.

4. Robinson, J.K., Freinkel, R.K., and Gotschalk, R. (1984) Br. J. Dermatol., 110, 17-27.

5. Watt, F.M., Keeble, S., Fisher, C., Hudson, D.L., Codd, J., and Salisbury, J.R. (1989) J. Cell Sci., 94, 355-359.

6. Zieske, J.D. and Bernstein, I.A. (1984) Biochem. Biophys. Res. Commun.,119, 1028-1033.

7. Ku, W. and Bernstein, I.A. (1985) Biochem. Biophys. Res. Commun., 132, 269-271.

8. Blake, D.A. and Goldstein, I.J. (1980) Anal. Biochem., 102, 103-109.

9. Gahmberg, C.G., and Hakomori, S.I. (1973) J. Biol. Chem., 248, 4311-4317.

10. Hinton, R.H. in G. D. Birnie, Editor, Subcellular Components: Preparation and Fractionation, pp. 119-156, Second Edition, 1972, Butterworths, London.

11. Vaughan, F.L., Kass, L.L. and Uzman, J.A. (1981) In Vitro , 17, 941-946.

12. Martin, A., Biol, M.C., Broquet, P., Richard, M. and Louisot, P.(1988) Enzyme, 39, 17-27.

13. Prieels, J.P., Monnom, D. and Perraudin, J.P. (1983) Eur. J. Biochem, 130, 347-351.

14. Broquet, P., Serres-Guillaumond, M. and Louisot, P. (1984) 16, 829-836.

15. Serres-Guilaumond,M., Broquet, P. and Louisot, P (1985) Can. J. Biochem. Cell. Biol., 63, 296-304.

16. Muramatsu, H., Kamada, Y. and Muramatsu, T.(1986) Eur. J. Biochem., 157, 71-75.

17. Sen, U., Guha, S., and Choudbury, J.P. (1985) Acta. Med. Okayama, 39, 125-130.

18. Ribeiro, P. (1988) The Repair of Bis(beta-chloroethyl)sulfid (BCES) Induced Alkylation Damage and Its Possible Role in the Survival of Exposed Primary Monolayer Cultures of Rat Cutaneous Keratinocytes. Thesis, The University of Michigan, Ann Arbor. 